HW -79793

UC-40, Radiation Effects

on Materials

(TID $-4500,31$ st Ed.)

\title{
MEASURING AND CORRELATING NEUTRON EXPOSURE AND DAMAGE IN GRAPHITE
}

By

R. E. Dahl

Material Research and Service

Reactor and Fuels Laboratory

Hanford Laboratories

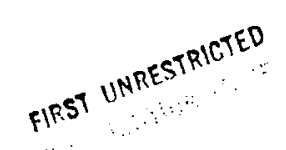

December 1963

\section{HANFORD ATOMIC PRODUCTS OPERATION \\ RICHLAND, WASHINGTON}

Work performed under Contract No. AT(45-1)-1350 between the Atomic Energy Commission and General Electric Company

Printed by/for the U.S. Atomic Energy Commission

Printed in USA. Price 50 cents. Available from the Office of Technical Services Department of Commerce Washington 25, D.C. 


\section{DISCLAIMER}

This report was prepared as an account of work sponsored by an agency of the United States Government. Neither the United States Government nor any agency Thereof, nor any of their employees, makes any warranty, express or implied, or assumes any legal liability or responsibility for the accuracy, completeness, or usefulness of any information, apparatus, product, or process disclosed, or represents that its use would not infringe privately owned rights. Reference herein to any specific commercial product, process, or service by trade name, trademark, manufacturer, or otherwise does not necessarily constitute or imply its endorsement, recommendation, or favoring by the United States Government or any agency thereof. The views and opinions of authors expressed herein do not necessarily state or reflect those of the United States Government or any agency thereof. 


\section{DISCLAIMER}

Portions of this document may be illegible in electronic image products. Images are produced from the best available original document. 
MEASURING AND CORRELATING NEUTRON EXPOSURE AND DAM AGE IN GRAPHITE

\section{INTRODUCTION}

This report describes methods for predicting service performance of graphite when the test-reactor environment differs from actual or anticipated environment. Although the application here is to graphite, the methods are applicable to other materials that are damaged by atomic displacements caused by reaction irradiation.

Correct interpretation of dosimetry data is critical to the determination of neutron exposure. The threshold monitors (Ni, Fe, Ti), which are used to monitor exposures in damage experiments, measure only about $10 \%$ of the neutrons which damage graphite. To extrapolate the activation data over an energy range sufficiently great to correlate damage, a neutron spectrum must be assumed or calculated. Unless the spectrum chosen is accurate, gross errors in exposure estimates will result.

Appropriate constants for the reduction of data in individual experiments are listed which will permit the experimenter to calculate neutron exposures with the best techniques currently available.

\section{$\underline{\text { SUMMARY }}$}

A procedure is described for measuring neutron exposure to graphite and for correlating radiation-damage data from different types of reactors. The fast-neutron spectrum is calculated and is, in turn, used to calculate the activation in threshold monitors such as nickel and iron. Nickel and iron are activated by neutrons with energies greater than about $3 \mathrm{MeV}$, so an effective cross section is computed to calculate exposures to neutrons with energies greater than $0.18 \mathrm{Mev}$. With these effective cross sections, activation monitors at several reactors yield exposures in agreement to $\pm 10 \%$.

The ratio of gross atomï-displacement rate to the flux greater than $0.18 \mathrm{Mev}$ was constant within $10 \%$ in several neutron spectra. If the magnitude of radiation-induced changes is proportional to displacement production, data from various reactors can be related by the exposure unit, nvt ( $\mathrm{E}>$ $0.18 \mathrm{Mev})$. 
Conversion units from megawatt day per adjacent ton to integrated fast flux have been tabulated. Results are $1.19 \times 10^{17} \mathrm{nvt} /(\mathrm{Mwd} / \mathrm{At})$ in the Hanford K-Reactor and $0.96 \times 10^{17} \mathrm{nvt} /(\mathrm{Mwd} / \mathrm{At})$ in the Hanford C-Reactor. IRRADIATION FACILITIES

The irradiation facilities that were analyzed included test positions in the Hanford Reactors, the General Electric Test Reactor (GETR), and the Engineering Test Reactor (ETR). The Hanford N-Reactor lattice was also analyzed in detail since the test data are used to predict property change in the $\mathrm{N}$-Reactor moderator.

Test holes in C- and $\mathrm{K}$-Reactors have been used extensively for graphite irradiations for many years. These are square holes which run through the graphite moderator normal to and between fuel channels in the reactor. The K-Reactor lattice and the representation used in the analyses are illustrated in Figure 1. C-Reactor is very similar except that the lattice pitch is $83 / 8$ in. Both reactors were analyzed in the same manner and cell-boundary spectra were used to obtain dosimetry and damage parameters for the facilities.

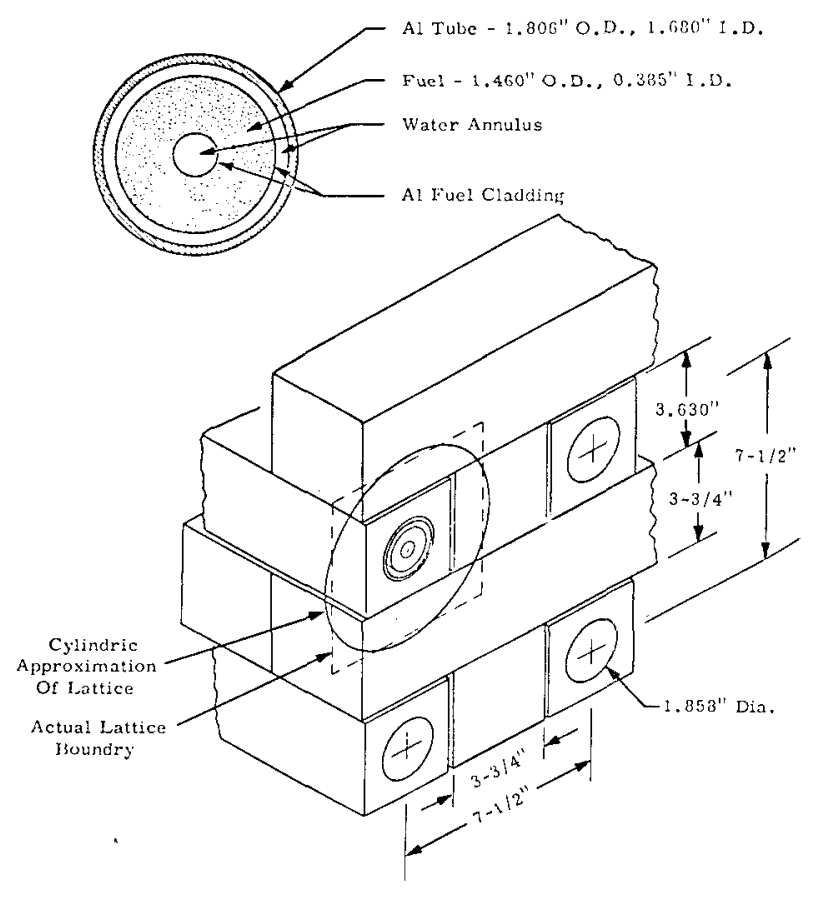

FIGURE 1 $\mathrm{K}$-Reactor Lattice and Process Tube Details 
Graphite irradiations are conducted in several positions in the northwest quadrant of the ETR (Figure 2) including E-5, F-6, and G-6. For the cases analyzed, "hot capsules" were located in E-5 and G-6 and a graphite creep test in F-6.

Positions in the GETR core used for graphite irradiations are illustrated in Figure 3.

The N-Reactor lattice analysis yielded parameters for each $1 / 2$ in. square in the lattice; however, data cited in this report represent an average for the area shaded in Figure 4 since this region is of principal interest.

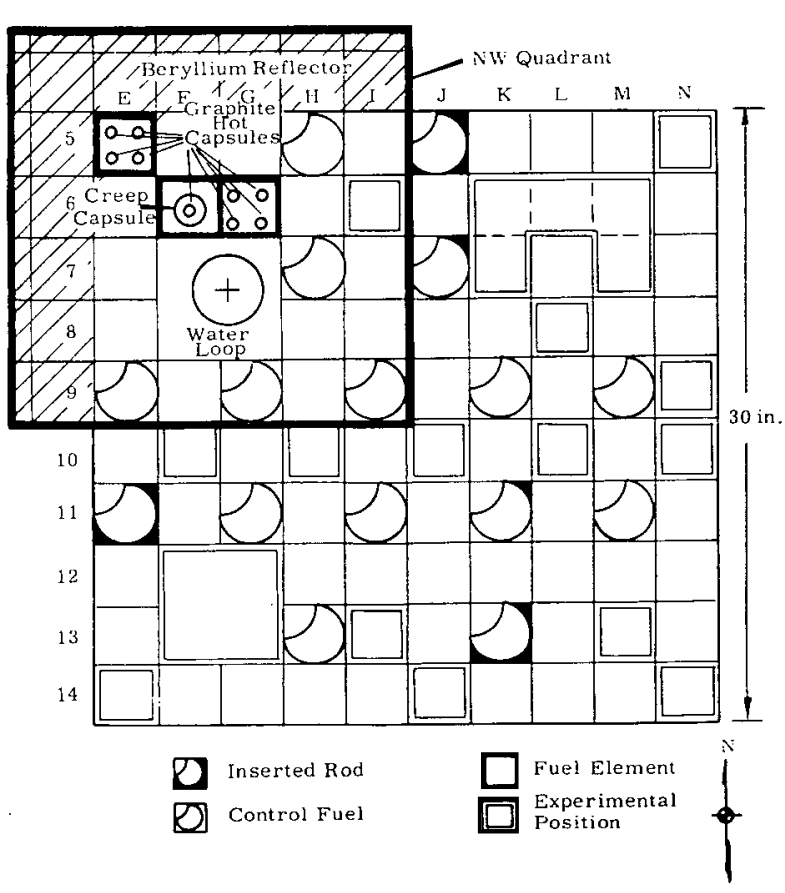

FIGURE 2

ETR Core

(The Northwest quadrant used in the flux calculations lies inside the heavy lines.)

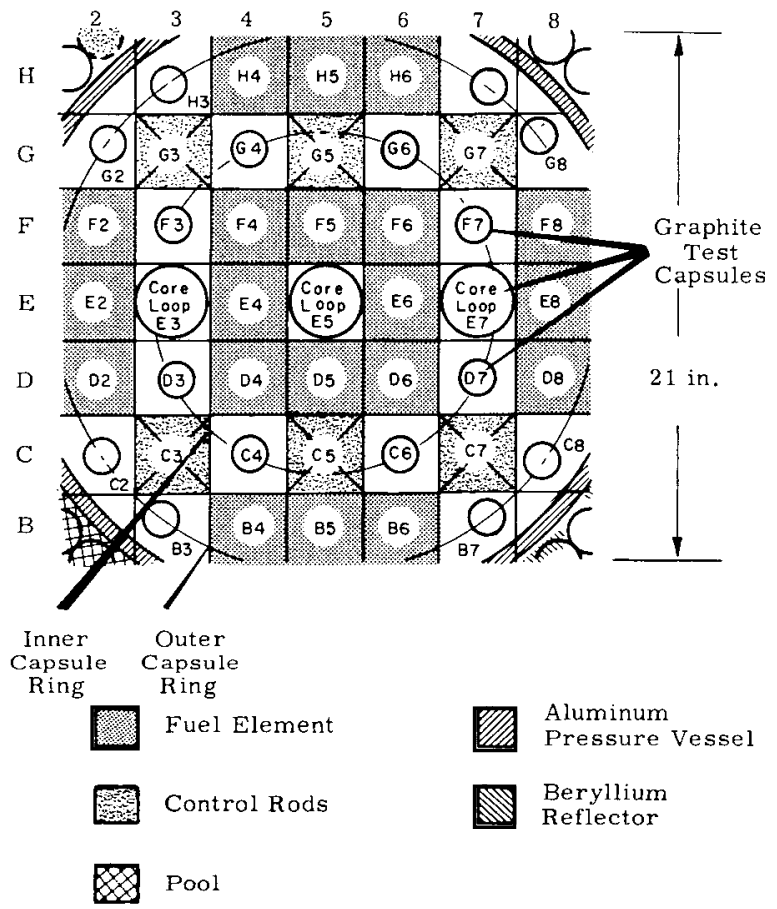

FIGURE 3

GETR Core as Represented for the Analysis

\section{CALCULATION PROCEDURE}

Neutron spectra were calculated with one of two codes, depending upon the geometry of the facility. Those with radial symmetry were calculated with PROGR AM S (GE-HAPO-S-12), (1) and the others were calculated 


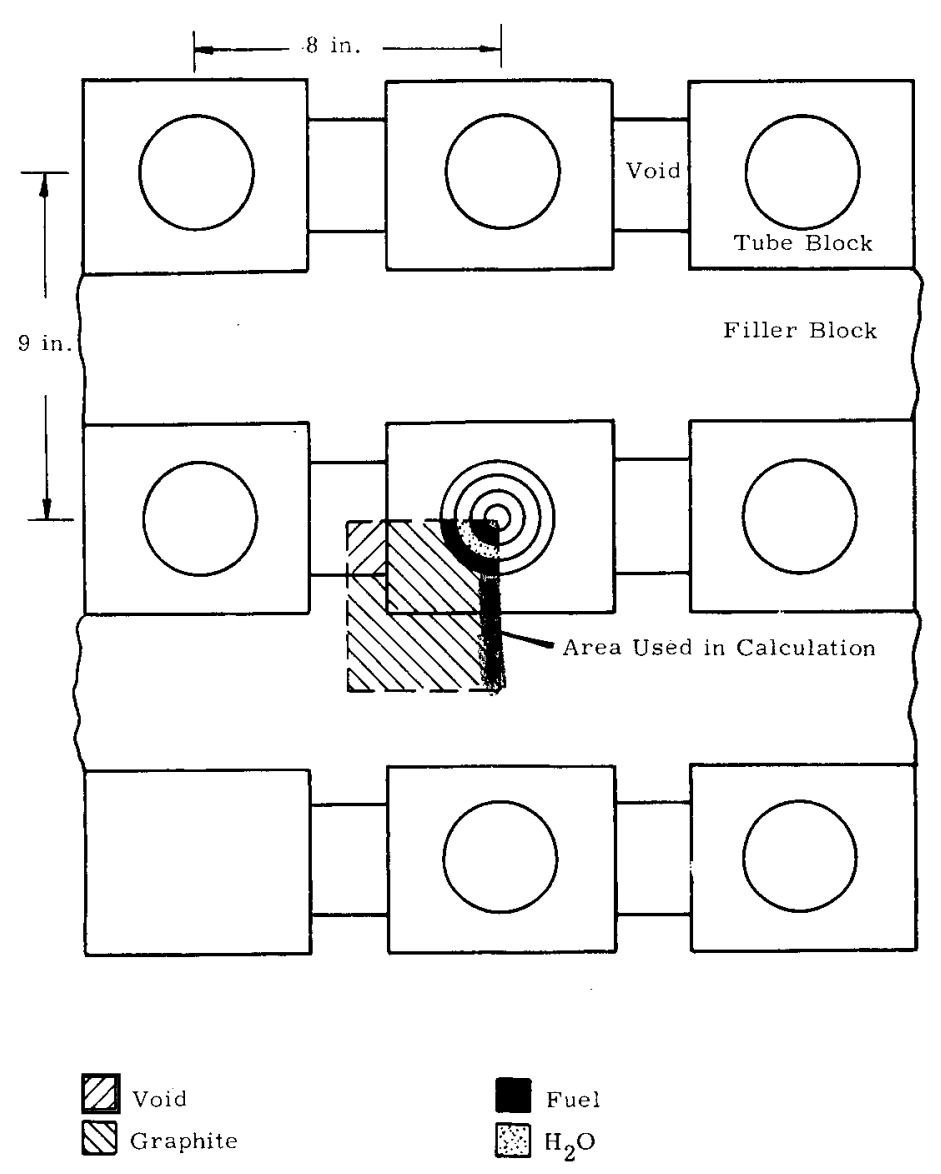

FIGURE 4

$\mathrm{N}$-Reactor Lattice and Area

Used in Transport-Theory Calculations

with 2DXY. (2) Both programs are multigroup, multiregion, transporttheory codes. All problems were solved with 16 energy groups in the range 0.18 to $10 \mathrm{Mev}$. Cases run with $2 \mathrm{DXY}$ were computed with two additional groups spanning the energy range below $0.18 \mathrm{Mev}$. Cases run with PROGRAM S utilized 17 energy groups below $0.18 \mathrm{Mev}$. Exact group structures are shown in Table I.

Flux-averaged cross sections for reactor materials used in the transport-theory analyses were generated by the GAMI ${ }^{(3)}$ code. Each reactor or lattice was homogenized and a spectrum calculated in a zero dimension analysis. These spectra were then used to obtain group averaged cross sections for reactor materials. 
$\underline{\text { TABLE I }}$

GROUP STRUCTURE AND GROUP AVERAGED CROSS SECTIONS

\begin{tabular}{|c|c|c|c|c|c|}
\hline \multirow[b]{2}{*}{ Group } & \multirow[b]{2}{*}{$E_{L}, e v^{*}$} & \multirow[b]{2}{*}{$\mathrm{U}_{\mathrm{L}}^{* *}$} & \multicolumn{3}{|c|}{$\sigma$, barns } \\
\hline & & & $\mathrm{Ni}^{58}(\mathrm{n}, \mathrm{p}) \mathrm{Co}^{58^{(4)}}$ & $\mathrm{Fe}^{54}(\mathrm{n}, \mathrm{p}) \mathrm{Mn}^{54^{(4)}}$ & $\begin{array}{l}\text { Displacement } \\
\text { Production } \\
\text { in Carbon }\end{array}$ \\
\hline 1 & $7.79 \times 10^{6}$ & 0.25 & 0.651 & 0.310 & 2378 \\
\hline 2 & $6.07 \times 10^{6}$ & 0.50 & 0.622 & 0.270 & 1739 \\
\hline 3 & $4.72 \times 10^{6}$ & 0.75 & 0.552 & 0.250 & 1646 \\
\hline 4 & $3.68 \times 10^{6}$ & 1.00 & 0.349 & 0.220 & 2691 \\
\hline 5 & $2.87 \times 10^{6}$ & 1.25 & 0.200 & 0.190 & 2964 \\
\hline 6 & $2.23 \times 10^{6}$ & 1.50 & 0.116 & 0.130 & 2653 \\
\hline 7 & 1. $74 \times 10^{6}$ & 1.75 & 0.048 & 0.050 & 2716 \\
\hline 8 & $1.35 \times 10^{6}$ & 2.00 & 0.015 & 0.005 & 2745 \\
\hline 9 & $1.05 \times 10^{6}$ & 2.25 & 0.004 & 0 & 3205 \\
\hline 10 & $8.21 \times 10^{5}$ & 2.50 & 0 & & 3078 \\
\hline 11 & $6.39 \times 10^{5}$ & 2.75 & & & 3063 \\
\hline 12 & $4.98 \times 10^{5}$ & 3.00 & & & 2970 \\
\hline 13 & $3.88 \times 10^{5}$ & 3.25 & & & 2817 \\
\hline 14 & $3.02 \times 10^{5}$ & 3.50 & & & 2573 \\
\hline 15 & $2.35 \times 10^{5}$ & 3.75 & & & 2321 \\
\hline 16 & $1.83 \times 10^{5}$ & 4.00 & & & 2030 \\
\hline 17 & $1.11 \times 10^{5}$ & 4.50 & & & 1496 \\
\hline 18 & $6.74 \times 10^{4}$ & 5.00 & & & 1060 \\
\hline 19 & $4.09 \times 10^{4}$ & 5.50 & & & 620 \\
\hline 20 & $2.48 \times 10^{4}$ & 6.00 & & & 380 \\
\hline 21 & $1.50 \times 10^{4}$ & 6.50 & & & 240 \\
\hline 22 & $9.12 \times 10^{3}$ & 7.00 & & & 140 \\
\hline 23 & $5.53 \times 10^{3}$ & 7.50 & & & 70 \\
\hline 24 & $2.04 \times 10^{3}$ & 8.50 & & & 30 \\
\hline 25 & 454 & 10.1 & & & 6 \\
\hline 26 & 130. & 11.25 & & & 0 \\
\hline 27 & 78.9 & 11.75 & & & \\
\hline 28 & 47.9 & 12.25 & & & \\
\hline 29 & 29.0 & 12.75 & & & \\
\hline 30 & 13.7 & 13.50 & & & \\
\hline 31 & 5.04 & 14.50 & & & \\
\hline 32 & 0.414 & 17.0 & & & \\
\hline 33 & 0 & $\infty$ & & & \\
\hline & $* E_{L} \quad E n$ & lower & group & & \\
\hline & $* * \mathrm{U}_{\mathrm{L}}$ & at lowe & y limit of group & & \\
\hline
\end{tabular}

The number of spatial zones utilized in the calculations depended upon the problem and the type of studies in the facility. Thirty-five regions were calculated in the Hanford $\mathrm{K}$ - and $\mathrm{C}$-Reactor lattices by PROGRAM S. The GETR and ETR cores and the N-Reactor lattice were analyzed with 2DXY. The GETR core was represented with 441 zones, each 1 by 1 in.; the ETR core with $3611 \times 1$ in. zones; and the N-Reactor lattice with 248 $1 / 2$ by $1 / 2$ in. zones. Materials were smeared within the zones. Each 3 by 3 irradiation position in the test reactors had 9 subdivisions, thus retaining a high degree of accurac'y and detail. All calculations were made on an IBM 7090 computer with approximately 8 to $10 \mathrm{hr}$ required for an analysis of each reactor or lattice. 
Spectra calculated for C-Reactor and for the ETR are shown in Figure 5 to illustrate differences in typical spectra in the two types of reactors.

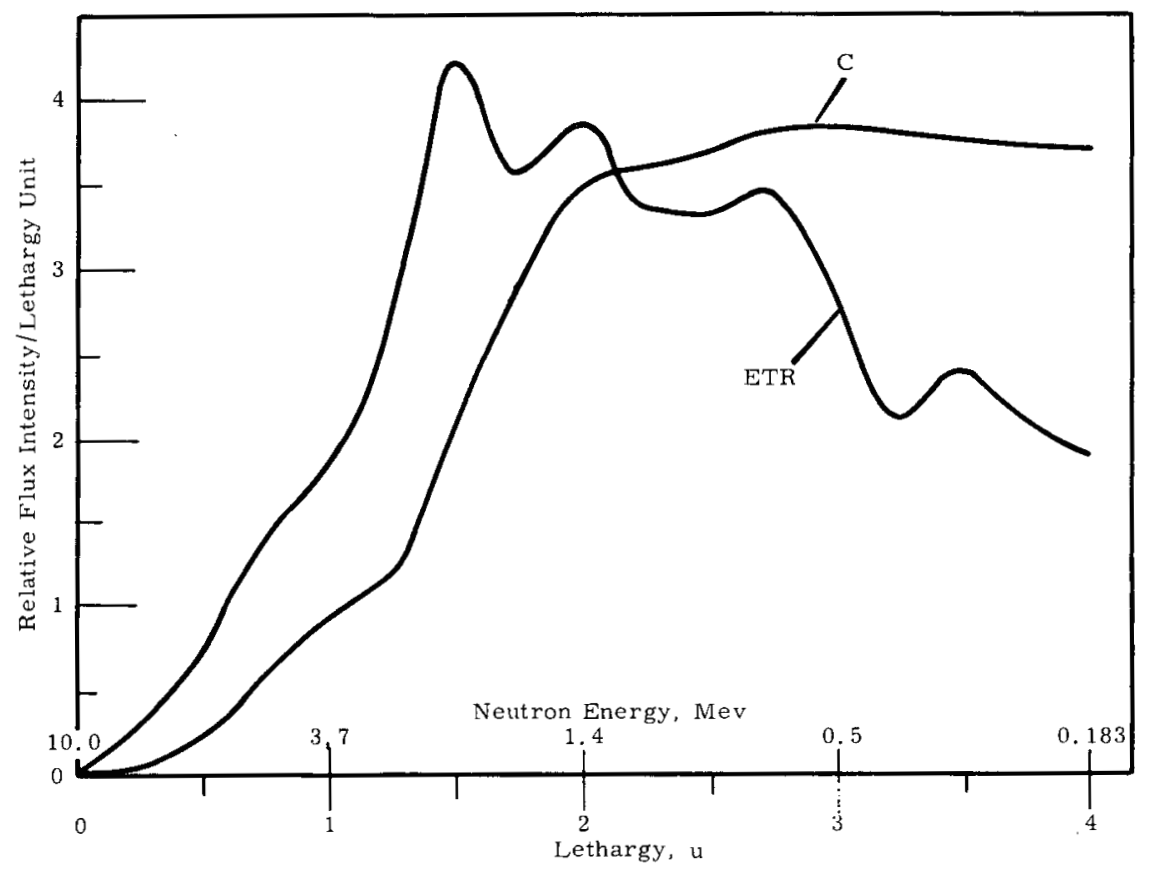

FIGURE 5

Flux Spectra in ETR Test Facility and a Graphite Moderated Reactor

\section{NEUTRON DOSIMETRY}

Neutron exposures for irradiation tests should be calculated from activation of monitors with effective cross sections appropriate for each irradiation facility. Fast-neutron exposures are monitored in irradiation tests by iron and nickel wires or foils. Radiochemical analysis of the products of the $\mathrm{Fe}^{54}(\mathrm{n}, \mathrm{p}) \mathrm{Mn}^{54}$ and $\mathrm{Ni}^{58}$ (n, p) Co ${ }^{58}$ reactions provide the basis for calculating the exposure. A major problem arises because the flux must be calculated over the energy range 0.18 to $10 \mathrm{Mev}$ to correlate graphite damage, yet the monitors are activated only by neutrons with energies above $3 \mathrm{Mev}$. Thus, an energy range below the activation range must be included through effective cross sections: ${ }^{(6)}$ 


$$
\sigma_{\text {eff }}=\frac{\int_{0}^{10(\mathrm{Mev}) \varphi(\mathrm{E}) \mathrm{dE}}}{\int_{\mathrm{E}_{\mathrm{O}}}^{10 \mathrm{Mev}} \varphi(\mathrm{E}) \mathrm{dE}}
$$

where $\sigma_{\text {eff }}$ is the effective cross section for energies greater than $\mathrm{E}_{\mathrm{O}}$ $\sigma(E)$ is the differential cross section for the nuclear reaction $\varphi(E)$ is the flux spectrum $\mathrm{E}_{\mathrm{O}}$ is the base energy for the effective cross section.

The differential cross-section data in Table I were used to calculate the effective cross sections presented in Table II. The variations between the effective cross sections in the test reactors and those in the Hanford reactors are due to spectral differences in the energy range, 0.18 to $3.0 \mathrm{Mev}$, that does not activate the monitors but that does cause the most radiation damage. The need for detailed analysis is apparent for accuracy in exposure determinations.

TABLE II

EFFECTIVE CROSS SECTIONS AND DISPLACEMENT PRODUCTION

\begin{tabular}{|c|c|c|c|c|c|}
\hline \multirow{2}{*}{$\begin{array}{c}\text { Reactor or } \\
\text { Irradiation Facility }\end{array}$} & \multirow{2}{*}{$\Phi^{*} \frac{(>0.18 \mathrm{Mev})}{\mathrm{Mwd} / \overline{\mathrm{A} t}} \times 10^{17}$} & \multirow{2}{*}{$\frac{(>0.18 \mathrm{MeV})}{>1 \mathrm{Mev}}$} & \multicolumn{2}{|c|}{$\sigma_{\text {eff }}(\Phi>0.18 \mathrm{Mev})$ mbarns } & \multirow{2}{*}{ 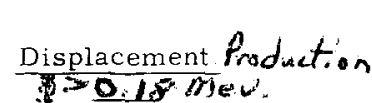 } \\
\hline & & & $\mathrm{Fe}^{54}(\mathrm{n}, \mathrm{p}) \mathrm{Mn}^{54}$ & $\mathrm{Ni}^{58}(\mathrm{n}, \mathrm{p}) \mathrm{Co}^{58}$ & \\
\hline N (See Figure 4) & 1.88 & 2.54 & & & 3283 \\
\hline $\mathrm{K}$ (Hot Test Hole) & 1.19 & 2. 60 & 27.7 & 38.1 & 3439 \\
\hline C (Hot Test Hole) & 0.95 & 2.64 & 27.9 & 38.6 & 3460 \\
\hline \multicolumn{6}{|l|}{ GETR } \\
\hline$D-7$ & & 2.00 & 40.2 & 62.4 & 3019 \\
\hline$E-7$ & & 1.82 & 51.4 & 84.3 & 3017 \\
\hline$F-7$ & & 1.98 & 40.3 & 62.6 & 3014 \\
\hline \multicolumn{6}{|l|}{ ETR } \\
\hline $\begin{array}{l}F-6 \\
G-6\end{array}$ & & 1.83 & 49,3 & 76.6 & 3022 \\
\hline NW & & 1.84 & 50.0 & 77.7 & 2961 \\
\hline $\mathrm{NE}$ & & 1.80 & 52.6 & 81.9 & 2929 \\
\hline $\mathrm{SE}$ & & 1.78 & 48.2 & 75.3 & 3017 \\
\hline SW & & 1.89 & 54.0 & 84.6 & 2939 \\
\hline \multicolumn{6}{|l|}{$E-5$} \\
\hline NW & & 2.23 & 26.6 & 39.6 & 3172 \\
\hline $\mathrm{NE}$ & & 1.95 & 43.1 & 66.9 & 3005 \\
\hline $\mathrm{SE}$ & & 1.86 & 40.4 & 61.9 & 3032 \\
\hline$S W$ & & 1.97 & 46.1 & 70.8 & 2973 \\
\hline
\end{tabular}


The accuracy of the effective cross sections, however, is no better than the accuracy of the differential cross sections. This is presently a severe problem with iron because of the very limited number of crosssection measurements at energies below $10 \mathrm{Mev}$. It has been necessary to postulate a differential cross section curve to develop effective cross sections. (4) Although application of the results yields exposures in good agreement with those determined with nickel monitors (within 15\%), better agreement can be expected as more cross-section measurements are made.

Effective cross sections have been calculated to give exposures in units that have been used to correlate graphite damage, i.e., E $>0.18 \mathrm{Mev}$. The values that have been presented can be converted to calculate $\Phi(E>1.0 \mathrm{Mev})$ :

$$
\sigma_{\text {eff }}[\Phi(\mathrm{E}>1.0 \mathrm{Mev})]=\sigma_{\text {eff }}\left[\Phi \text { eff }[\Phi(\mathrm{E}>0.18 \mathrm{Mev})] \frac{\Phi(E>0.18 \mathrm{Mev})}{\Phi(\mathrm{E}>1.0 \mathrm{Mev})} .\right.
$$

The flux ratio for each irradiation facility is presented in Table II.

The effective cross sections presented in this report have been used to calculate exposures for irradiation experiments in the ETR, (7) and for the first time agreement has been obtained between exposures calculated from nickel and from iron monitors. These data (Table III) show agreement within about $15 \%$ in most of the experiments. This agreeis of particular'significance since.it enables one to place more reliance on exposures calculated from iron monitors.

TABLE III

EXPOSURES $\Phi(E>0.18$ Mev) CALCULATED FROM MONITORS

IRRADIATED IN THE G-6 FACILITY IN THE ETR

\begin{tabular}{cccc} 
Capsule & $\begin{array}{c}\text { Distance from Top } \\
\text { of Core, } \\
\text { in. }\end{array}$ & $\frac{\Phi \mathrm{t} \times 10^{-21}(\mathrm{E}>0.18 \mathrm{Mev})}{\mathrm{Ni}}$ \\
\cline { 2 - 4 } 162 & 6 & 1.02 & 0.91 \\
163 & 12 & 1.18 & 1.30 \\
164 & 18 & 1.31 & 1.43 \\
165 & 24 & 1.16 & 1.19 \\
166 & 30 & 0.76 & 0.82 \\
176 & 6 & 0.51 & 0.98 \\
177 & 12 & 1.60 & 1.53 \\
178 & 18 & -- & 1.00 \\
180 & 24 & 1.38 & 1.20 \\
180 & 30 & 0.86 & 0.84
\end{tabular}

\section{DAMAGE NORMALIZATION}

Correlation of radiation-effects data is often very difficult because of the influence of spectra on damage accumulation. Theory ${ }^{(8)}$ has indicated 
that, if exposures for graphite are measured in units of neutrons per flux integrated for energies greater than $0.065 \mathrm{Mev}$, spectral differences are normalized. Recently, exposures for graphite irradiations have been expressed as flux greater than $0.18 \mathrm{Mev}$, nvt ( $\mathrm{E}>0.18 \mathrm{Mev}$ ). Displacement rates per integrated flux ( $\mathrm{E}>0.18 \mathrm{Mev}$ ) have been calculated for each facility according to the de Halas model ${ }^{(5)}$ and are presented in Table II. These ratios are constant to withị $\pm 10 \%$, demonstrating that this normalization base nearly corrects for spectral variation and is quite accurate.

Further refinement is readily attained by correlating exposures between facilities with these ratios. As an example, the ratio of displacements to integrated flux for $\mathrm{N}$-Reactor is $\overline{\mathbf{3 2 8 3}}$ and that for the D-7 facility in the GETR is $\overline{3019}$; thus, an integrated exposure of $10^{21} \mathrm{nvt}(\mathrm{E}>0.18)$ would cause $\frac{3283}{3019}$ or 1.09 times the number of carbon-atom displacements in N-Reactor than in D-7. An "effectiveness". index for the facilities is thereby established.

The effects of spectral variation on damage accumulation in graphite, and the need for detailed spectral determinations are illustrated in Figure 6 . The fraction of total displacement production is plotted against neutron lethargy for the GETR, the C-Reactor spectrum, and for an unmoderated Watt fission spectrum. Damage accumulation is quite different. Neutrons with energy above 1 Mev cause approximately $90 \%$ of the total damage in a fission spectrum but only about $35 \%$ of the total damage in the $\dot{C}$-Reactor spectrum. The lower energy flux component, $0.1 \mathrm{Mev}>\mathrm{E}>0.005$, causes $20 \%$ of the damage in the relatively well moderated C-Reactor spectrum but less than $5 \%$ in the GETR. Finally, neutrons with energy greater than $3 \mathrm{Mev}$, which produce activation in monitors, cause less than $5 \%$ of the total damage in the three spectra. Detailed knowledge of reutron spectra are, therefore, essential if accurate damage studies are to be made.

CONVERSION OF EXPOSURE DATA TO REACTOR ENERGY PRODUCTION

Conversion between fast neutron exposure units such as nvt $(\mathrm{E}>0.18$ Mev) and units of energy production in fuel adjacent to experiments is of interest because a great deal of data have been presented in each system. 


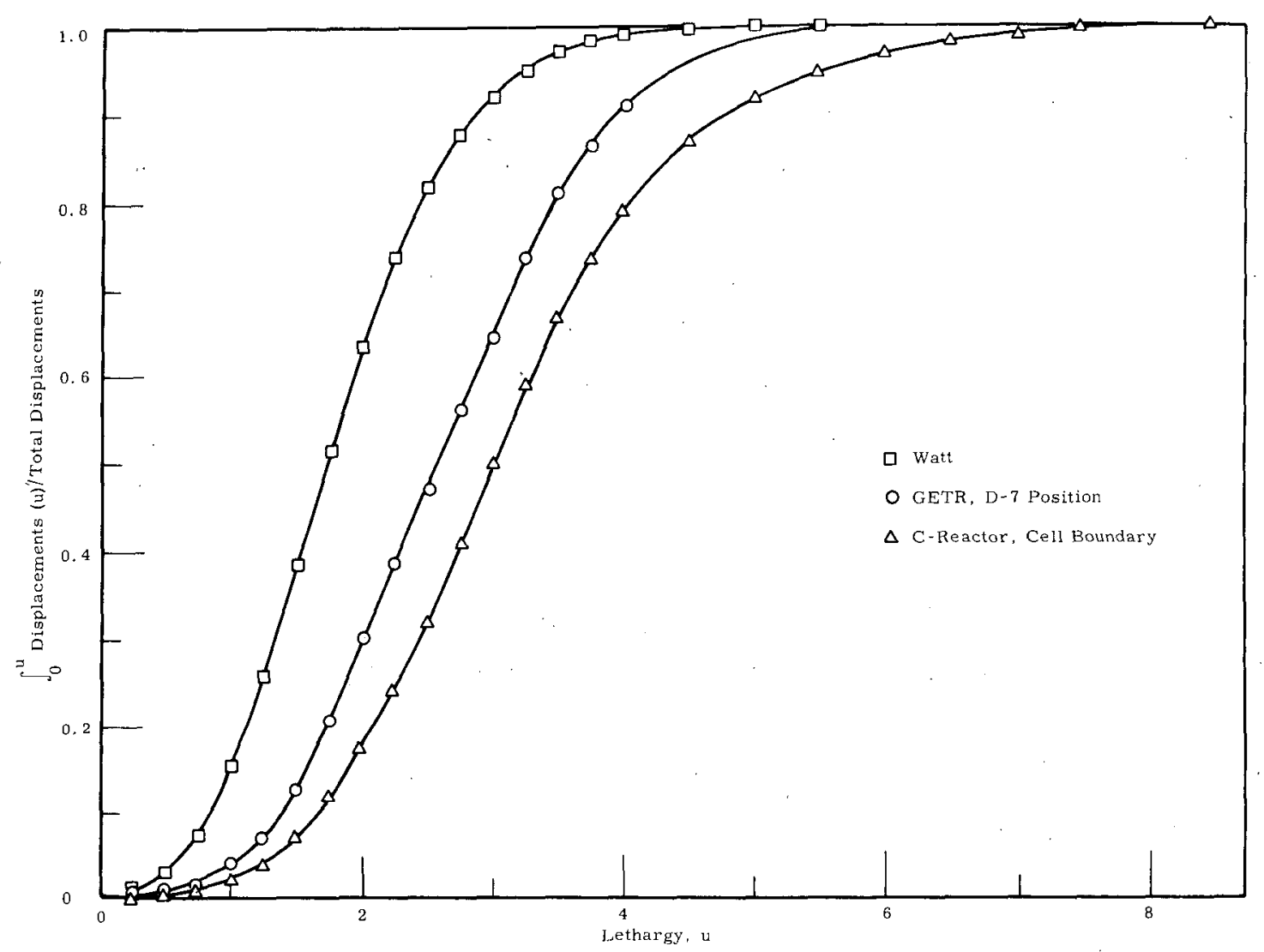

FIGURE 6

Displacement Production $\overline{\text { Modes }}$ in Several Neutron Spectra

Units of megawatt days per adjacent ton of fuel are used to express exposure in terms of local energy generation.

Conversion factors have been calculated, according to the method derived in the Appendix, that give the ratio of flux ( $\mathrm{E}>0.18 \mathrm{Mev}$ ) to $\mathrm{Mwd} / \mathrm{At}$, in three Hanford reactors and are presented in Table II. Values'cited for $\mathrm{C}$ - and $\mathrm{K}$-Reactors are applicable to hot test hole facilities within the fueled region of the reactor. The value for $\mathrm{N}$-Reactor was calculated to apply to the graphite in a tube block directly under the tube.

Significant differences in the conversion ratios may be noted among the three reactors, $\mathrm{C}, \mathrm{K}$, and $\mathrm{N}$. Although all are graphite moderated and somewhat similar in core design, a factor of 2 is obtained between 
$\mathrm{C}$ and $\mathrm{N}$, and a $25 \%$ difference between $\mathrm{C}$ and $\mathrm{K}$. These differences are primarily due to differences in the fuel-to-moderator ratios in the reactors. However, the most striking fact is that if damage estimates are made on the basis of Mwd/At exposures, errors of $100 \%$ would result. These errors would occur because reactor power is proportional to the thermal flux, whereas damage is dependent on the fast flux. Ratios of fast-to-thermal flux are considerably different among facilities and can vary significantly during an irradiation cycle in any particular facility. Since variation exists, it is necessary to specify the reactor upon which the Mwd/At normalization is based. This is not necessary for exposures which are properly normalized in terms of integrated fast flux; hence, the latter unit is more accurate and convenient.

The conversion ratios presented in this report were obtained from reactor analysis computations. Since these ratios are the basis for exposure normalization for a great deal of irradiation test data, it was neces sary to check the ratios with experimental observations as closely as possible. Ideally one would experimentally measure the flux $(\Phi \mathrm{E}>0.18$ Mev) in an irradiation facility and power generation in the adjacent fueled region. Power generation can be measured with reasonable accuracy, but fast flux ( $\Phi \mathrm{E}>0.18 \mathrm{Mev}$ ) must be determined through the use of effective cross sections. A completely independent check is not possible. The most pertinent check is a determination of the ratio from monitor data reduced with the effective cross sections calculated for the position and local power generation measurements.

Morgan (9) calculated the conversion ratios in Table II to check the theoretical anaiysis, using the effective cross sections for nickel presented in Table I to calculate the fast flux ( $\Phi \mathrm{E}>0.18 \mathrm{Mev})$; tube-power data were obtained from reactor operational records. The local power generation. (Mwd/At) was calculated by assuming a chopped cosine distribution of power along the tubes adjacent to the irradiation position. Fluxto-power ratios were calculated with monitor data from ten experiments irradiated in a hot test hole in $\mathrm{K}$-Reactor. Ratios ranged between $1.17 \mathrm{x}$ $10^{17} \mathrm{nvt} /(\mathrm{Mwd} / \mathrm{At})$ and $1.37 \times 10^{17} \mathrm{nvt} /(\mathrm{Mwd} / \mathrm{At})$. The average of these data was $1.24 \pm 0.09 \times 10^{17} \mathrm{nvt} /(\mathrm{Mwd} / \mathrm{At})$ which agrees very well with 
the theoretical value of $1.19 \times 10^{17}$. Similar experiments in a C-Reactor hot test hole yielded ratios that ranged from $0.775 \times 10^{17}$ to $1.14 \times 10^{17}$ and averaged $0.959 \times 10^{17}$; this may be compared to the theoretical value of $0.953 \times 10^{17}$. The agreement between theoretical calculatiuns and the experimental data is very good especially in this type of facility. These ratios can, therefore, be used with confidence in resolving data generated in the past in these facilities.

ACKNOWLEDGEMENTS

The author is grateful for the help received from many people. In particular, the patient help of B. H. Duane in the use of transport theory analyses and the Appendix, "Derivation of Exposure Unit Conversion", was essential. Discussions with and help received from J. A. Ulseth, H. H. Yoshikawa, J. W. Helm, and W. C. Morgan were invaluable. 


\section{$\underline{\text { REFERENCES }}$}

1. B. H. Duane. Neutron and Proton Transport Plane-Cylinder-Sphere (GE-ANPD) Program SVariational Optinum Formulation, XDC-59118. General Electric Co. (ANPD), Cincinnati, Ohio, January 9, 1959.

2. J. Bengston, S. T. Perkins, T. W. Sheheen, and D. 'W. Thompson. Army Gas Cooled Reactor Systems Program 2DXY Two Dimensional, Cartesian Coordinate $S_{n}$ Transport Calculation, AGN-TM-392. June, 1961.

3. G. D. Joanou and J. S. Dudek. GAM-1: A Consistent P 1 Multigroup Code for the Calculation of Fast Neutron Spectra and Multigroup Constants, GA-1850. General Atomics Division, General Dynamics Corporation, 1961.

4. J.W. Helm, Unpublished Data, General Electric Co., Richland, Washington, 1964. (Interim Report 3)

5. D. R. deHalas. "Theory of Radiation Effects in Graphite, "Nuclear Graphite, edited by R. E, Nightingale, Academic Press, New York, 1962. pp. 215-217.

6. R. E. Dahl and H. H. Yoshikawa. "Neutron-Spectra Calculations for Radiation-Damage Studies, "Nuclear Science and Engineering, vol. 17, pp. 398-403. November, 1963.

7. H. H. Yoshikawa. Unpublished Data, General Electric Co., Richland, Washington.

8. R. E. Dahl and H. H. Yoshikawa. "A Proposed Exposure Unit for Radiation-Damage Studies, "Trans. Am. Nuc. Soc., vol. 7, pp. 125-126. June, 1964.

9. W. C. Morgan and H. H. Yoshikawa. Unpublished Data, General Electric Co., Richland, Washington, 1964. (Interim Report 3) 


\section{APPENDIX}

\section{DERIVATION OF EXPOSURE UNIT CONVERSION}

The ratio between integrated fast flux in a test facility and local power generation is basically obtained from a transport theory analysis of the lattice. This analysis gives the ratio of the fission rate in the fueled zone to the flux in the zone used for irradiation testing. This ratio is then multiplied by constants to obtain the conventional units of megawatt. days per adjacent ton.

When computing these ratios a complication is introduced since the transport theory analyses were made in either one or two dimensions with the inherent assumption that the system was invariant in the other dimensions. These were satisfactory approximations in the Hanford reactors.

The equation which relates the fast flux in one zone to power generation in another is derived for use within transport-theory analyses is as follows.

The flux integrated over the energy range that correlates radiation damage, and over the zone in which radiation damage occurs is:

$$
\Phi d t=\frac{\int_{Z_{1}}^{Z_{2}} \int_{Y_{1}}^{Y_{2}} \int_{X_{1}}^{X_{2}} \int_{E_{O}}^{D_{0}} \Phi(E, X, Y) d E d X d Y d Z}{\int_{Z_{1}}^{Z_{2}} \int_{Y_{1}}^{Y_{2}} \int_{X_{1}}^{X_{2}} d X d Y d Z} .
$$

The fission rate per atom of fuel (uranium) in the adjacent fuel is:

$$
\frac{d U_{f}}{U}=\frac{\int_{Z_{1}}^{Z_{2}} \int_{Y}^{Y^{\prime}} \int_{X_{0}}^{X^{\prime}} \int_{0}^{\infty} \Phi(E, X, Y) \Sigma_{f}(E, X, Y) d E d X d Y d Z}{\int_{Z_{1}}^{Z_{2}} \int_{Y_{O}}^{Y^{\prime}} \int_{X_{O}}^{X^{\prime}} N_{u}(X, Y) d X d Y d Z}
$$


In Equations 1 and 2

$Z_{1}$ and $Z_{2}$ are the limits of integration in the $Z$ domain and are the same in each integration.

$X_{1}, X_{2}, Y_{1}$, and $Y_{2}$ are the spatial limits of the fuel.

$\mathrm{X}_{0}, \mathrm{X}^{\prime}, \mathrm{Y}_{\mathrm{O}^{\prime}}$, and $\mathrm{Y}^{\prime}$ are the spatial limits of the irradiation testing facility.

$\mathrm{E}_{\mathrm{O}}$ is the lower energy limit used to correlate radiation damage in material.

$\frac{d U_{f}}{U}$ is the fission rate of fuel (uranium) per second per uranium atom.

$\Sigma_{f}$ is the macroscopic fission cross section $=\sigma_{f} N_{u}$.

$\mathrm{N}_{\mathrm{u}}$ is the concentration of uranium atoms per unit volume.

The elements in Equations 1 and 2 are obtained from the transport theory analyses. Thus, if Equation 1 is divided by Equation 2 one obtains: $\frac{\Phi d t}{\left(\frac{d U_{f}}{U}\right)}$ which is the integrated flux per fission. To convert this to local

power generation the constant relating power per fission and one defining average fuel loading are introduced. Thus

$$
\frac{\Phi}{\mathrm{P} / \mathrm{M}}=\frac{\Phi \mathrm{dt} A \bar{\rho}_{\mathrm{u}}}{\left(\frac{\mathrm{dU}}{\mathrm{U}}\right) \mathrm{N}_{\mathrm{u}} \mathrm{B}}=\frac{\Phi\left(\mathrm{E}>\mathrm{E}_{\mathrm{o}}\right)}{\mathrm{P} / \mathrm{M}}[\Phi(\mathrm{Mwd} / \mathrm{At})]
$$

where $A=3.70 \times 10^{-22} \frac{\text { Mwd }}{\text { fission }}$, based on $\frac{200 \mathrm{Mev}}{\text { fission }}$

$$
\begin{aligned}
P & =\text { power } \\
M & =\text { mass of uranium } \\
\mathrm{N}_{\mathrm{u}} & =\text { uranium atoms } / \mathrm{cm}^{3} \\
\bar{\rho}_{\mathrm{u}} & =\text { uranium density averaged over fuel channel }\left(\mathrm{g} / \mathrm{cm}^{3}\right) \\
\mathrm{B} & =\mathrm{g} / \text { ton }
\end{aligned}
$$


INTERNAL DISTRIBUTION

Copy Number

$\begin{array}{ll}1 & \text { F. W. Albaugh } \\ 2 & \text { D. E. Baker } \\ 3 & \text { A. L. Bement, Jr. } \\ 4 & \text { S. H. Bush } \\ 5 & \text { J. J. Cadwell } \\ 6 & \text { T. T. Claudson } \\ 7 & \text { D. H. Curtiss } \\ 8-17 & \text { R. E. Dahl } \\ 18 & \text { R. L. Dillon } \\ 19 & \text { B. H. Duane } \\ 20 & \text { R. C. Giberson } \\ 21 & \text { J. Greenborg } \\ 22 & \text { J. W. Helm } \\ 23 & \text { J. L. Jackson } \\ 24 & \text { S. S. Jones } \\ 25 & \text { W. C. Morgan } \\ 26 & \text { R. Neidner } \\ 27-71 & \text { R. E. Nightingale } \\ 72 & \text { J. C. Tobin } \\ 73 & \text { E. E. Voiland } \\ 74 & \text { E. M. Woodruff } \\ 75 & \text { H. H. Yoshikawa } \\ 76-80 & \text { Extra } \\ 81 & \text { 300 File } \\ 82 & \text { Records Center } \\ 83 & \text { Technical Publications } \\ & \end{array}$

EXTERNAL DISTRIBUTION (Special)

No. of Copies

1

1

3

2

2
Argonne National Laboratory

Attn: A. D. Rossin

Atomic Energy Commission, Washington Military Liaison Committee

Attn: Captain D. E. McCoy, Staff Assistant to the Chairman

Atomic Energy Commission, Washington

Attn: J. G. Conner

W. L. R. Rice

J. M. Simmons

Battelle Memorial Institute

Attn: B. P. Fairand

D. Sunderman

General Atomic Division

Attn: G. B. Engle

R. A. Meyer 
EXTERNAL DISTRIBUTION (Special) Contd)

No. of Copies

1

1

1

1

1

1
Great Lakes Carbon Corporation

P.O. Box 637, Niagara Falls, New York Attn: L. H. Juel, Technical Director Graphite Products Division

IIT Research Institute Attn: W. N. McElroy

National Carbon Company

Division of Union Carbide Corp.

270 Park Ave., New York 17, N. Y. Attn: L. Stoughton, Manager Nuclear Products

National Carbon Company

Research Laboratories

P.O. Box 6116, Cleveland, Ohio Attn: J. T. Meers

Phillips Petroleum Company Attn: C. H. Hogg Speer Carbon Company Research and Development Laboratories Packard Road \& 47th Street Niagara Falls, N.Y. Attn: W. E. Parker Union Carbide Corporation (ORNL) Attn: M. S. Wechsler General Electric Technical Data Center, Schenectady RLOO Technical Library 


$\begin{array}{cl}\text { Ptd } & \text { Standard Distribution } \\ 11 & \text { ABERDEEN PROYING GROUND } \\ 1 & \text { AEROJET-GENERAL CORPORATION } \\ 1 & \text { AEROJET-GENERAL NUCLEONICS } \\ 2 & \text { AERONAUTICAL SYSTEMS DIVISION }\end{array}$

AIR FORCE WEAPONS LABORATORY BETHESDA

ALLISON DIVISION-GMC

ARGONNE NATIONAL LABORATORY INSTITUTE LABCRATORIES

ARMY ELECTRONICS RESEARCH AND DEVELOPMENT LABORATORIES MENT LABORATORIES

*ARMY MATERIEL COMMAND (DN.RE)

ARMY MISSILE COMMAND

ARMY NATICK LABORATORIES

ARMY RESEARCH OFFICE, DURHAM

ARMY TANK-AUTOMOTIVE CENTER
Ptd.

2

4

AIR FORCE INSTITUTE OF TECHNOLOGY

ALLIS.CHALMERS MANUFACTURING COMPAKY

ALLIS-CHALMERS MANUFACTURING COMPANY,

*ARMEO FORCES RADIOBIOLOGY RESEARCH

ARMY CHEMICAL RESEARCH AND DEVELOPMENT

ARMY ENGINEER RESEARCH AND DEVELOP.

*ARMY HARRY DIAMOND LABORATORIES

ARMY MATERIALS RESEARCH AGENCY

ARMY NUCLEAR DEFENSE LABORATORY

ATOMIC ENERGY COMMISSION, BETHESDA

AEC SCIENTIFIC REPRESENTATIVE, BELGIUM

AEC SCIENTIFIC REPRESENTATIVE, FRANCE

AEC SCIENTIFYC REPRESENTATIVE, JAPAN

ATOMIC ENERGY COMMISSION, WASHINGTON

ATOMIC ENERGY OF CANADA LIMITED
Standard Distribution

ATOMIC ENERGY OF CANADE LIMITED, MHITESHELL

*atomics INTERNATIONAL

BABCOCK AND WILCOX COMPANY

BATTELLE MEMORIAL INSTITUTE

BEERS (ROLAND F.), INC.

BROOKHAVEN NATIONAL LABORATORY

BUREAU OF MINES, ALBANY

BUREAU OF MINES, WASHINGTON

BUREAU OF NAYAL WEAPONS

BUREAU OF SHIPS (CODE 1500)

BUREAU OF YARDS AND DOCKS

CARNEGIE INSTITUTE OF TECHNOLOGY

CHICAGO PATENT GROUP

COMBUSTION ENGINEERING, INC.

COMBUSTION ENGINEERING, INC. (NRD)

DEFENCE RESEARCH MEMBER

DENYER RESEARCH INSTITUTE

DU PONT COMPANY, AIKEN

DU PONT COMPANY, WILMINGTON

EDGERTON, GERMESHAUSEN AND GRIER, INC., GOLETA

EDGERTON, GERMESHAUSEN AND GRIER, INC., LAS YEGAS

EDGEWOOD ARSENAL

FRANKFORD ARSENAL

FRANKLIN INSTITUTE OF PENNSYLVANIA

FUNDAMENTAL METHODS ASSOCIATION

GENERAL ATOMIC DIVISION

GENERAL DYNAMICS/FORT WORTH

GENERAL ELECTRIC COMPANY, CINCINNATI

GENERAL ELECTRIC COMPANy, PLEASANTON

GENERAL ELECTRIC COMPANY, SAN JOSE 
TID-4500

(32nd Ed.)

PIL

l

I

1

1

1

1

1

4

1

1

I

2

1

1

1

1

1

1

2

2

1

1

1

1

2
Standard Distribution

GENERAL NUCLEAR ENGINEERING CORPORATION

GOODYEAR ATOMIC COR PORATION

HAZLETON NUCLEAR SCIENCE OORPORATION HUGHES AIRCRAFT COMPANY

IOWA STATE UNIVERSITY

JET PROPULSION LABORATORY

JOHNS HOPKINS UNIVERSITY

KNOLLS ATOMIC POWER LABORATORY

LING TEMCO VOUGHT, INC.

LOCKHEED-GEORGIA COMPANY

LOCKHEE D MISSILES AND SPACE COMPANY (NASA)

LOS ALAMOS SCIENTIFIC LABORATORY

MARITIME ADMINISTRATION

MARTIN-MARIETTA CORPORATION

MONSANTO RESEARCH CORPORATION

MOUND LABORATORY

NASA AMES RESEARCH CENTER

NASA LEWIS RESEARCH CENTER

NASA LEWIS RESEARCH CENTER, SANDUSKY

NASA MANNED SPACECRAFT CENTER

NASA SCIENTIFIC AND TECHNICAL INFORMA. TION FACILITY

NATIONAL BUREAU OF STANDARDS

NATIONAI. BUREAU OF STANDARDS (LIBRARY)

NATIONAL INSTITUTES OF HEALTH

NATIONAL LEAD COMPANY OF OHIO

NAVAL CIVIL ENGINEERING LABORATORY

NAYAL MEDICAL RESEARCH INSTITUT.E

MAYAL ORDNANCE LABORATORY

NAYAL POSTGRADUATE SCHOOL

NAYAL RADIOLOGICAL DEFENSE LABORATORY

UC-40

Ptd.

3

1

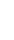

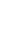

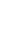

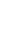

d.

(1)

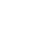

1

1

1

1

1

5

1

1

1

1

1

4

1

1

1

3

1

2

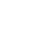

1

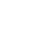

1

Standard Distribution

NAYAL RESEARCH LABORATORY

NAYAL WEAPONS EVALUATION FACILITY

NEW YORK OPERATIONS OFFICE

NUCLEAR MATERIALS AND EQUIPMENT CORPORATION

NUCLEAR METALS, INC.

NUCLEAR UTILITY SERVICES, INC.

OFFICE OF ASSISTANT GENERAL COUNSEL FOR PATENTS (AEC)

OFFICE OF NAYAL RESEARCH

OFFICE OF NAYAL RESEARCH (CODE 422)

OFFICE OF THE CHIEF OF ENGINEERS

OFFICE OF THE CHIEF OF NAVAL OPERATIONS

OHIO STATE UNIVERSITY

PENNSYLYANIA STATE UNIVERSITY

PHILLIPS PETROLEUM COMPANY (NRTS)

PHYSICS INTERNATIONAL, INC.

PICATINNY ARSENAL

POWER REACTOR DEVELOPMENT COMPANY

PRATT AND WHITNEY AIRCRAFT DIVISION

PRINCETON UNIVERSITY (SHERR)

PUBLIC HEALTH SERVICE

PUBLIC HEALTH SERVICE, LAS VEGAS

PUBLIC HEALTH SERVICE, MONTGOMERY

PURDUE UNIVERSITY

RADIATION APPLICATIONS, INC.

RADIOPTICS, INC.

RAND CORPORATION

RENSSELAER POLYTECHNIC INSTITUTE

ROCKY MOUNTAIN ARSENAL

SANDIA CORPORATION, ALBUQUERQUE

SANDIA CORPORATION, LIVERMORE

SCHOOL OF AEROSPACE MEDICINE

SPACE TECHNOLOGY LABORATORIES, INC. (NASA) 


$\begin{array}{cl}\text { Ptd. } & \text { Standard Distribution } \\ 1 & \text { STANFORD UNIVERSITY (SLAC) } \\ 1 & \text { STRATEGIC AIR COMMAND } \\ 1 & \text { SYLVANIA ELECTRIC PRODUCTS, INC. } \\ 1 & \text { TENNESSEE YALLEY AUTHORITY } \\ 1 & \text { TEXAS NUCLEAR CORPORATION } \\ 1 & \text { TRACERLAB, INC., RICHMOND } \\ 2 & \text { UNION CARBIDE. CORPORATION (ORGOP) } \\ 6 & \text { UNION CARBIDE CORPORATICN (ORNL) } \\ 1 & \\ 1 & \text { UNITED NUCLEAR CORPORATION (NDA) } \\ 1 & \text { U. S. GEOLOGICAL SURVE, DENVER } \\ 1 & \text { U. S. GEOLOGICAL SURVEY, WASHINGTON }\end{array}$

$\begin{array}{cl}\text { Pld. } & \text { Staridard Distribution } \\ 2 & \text { UNIVERSITY OF CALIFORNIA, BERKELEY } \\ 2 & \text { UNIVERSITY OF CALIFORNIA, LIVERMORE } \\ 1 & \text { UNIVERSITY OF PUERTO RICO } \\ 1 & \text { UNIVERSITY OF ROCHESTER } \\ 1 & \text { UNIVERSITY OF ROCHESTER (MARSHAK) } \\ 4 & \text { WESTINGHOUSE BETTIS ATOMIC POWER } \\ & \text { LABORATURY } \\ 1 & \text { WESTINGHOIISE ELECTRIC CORPORATION } \\ 1 & \text { WESTINGHOUSE ELECTRIC CORPORATION } \\ \text { (NASA) } & \text { WHITE SANDS MISSILE RANGE } \\ 1 & \text { DIVISION OF TECHNICAL INFORMATION } \\ 325 & \text { EXTENSION } \\ 75 \dagger & \text { OFFICE OF TECHNICAL SERVICES, } \\ & \text { WASHINGTON }\end{array}$

